\title{
The Death of the European Agency
} for Reconstruction: A Peculiar Case of Termination of the Agencies of the European Union

\author{
Islam Jusufi* \\ https://doi.org/10.31297/hkju.21.4.3 \\ UDK: $\quad 35.072 .6(497.5)$ \\ 342.97(4)EU \\ 341.176:35.072.6(4)EU \\ Original scientific paper / izvorni znanstveni rad \\ Received/primljeno: 9. 3.2021. \\ Accepted/prihvaćeno: 26.11.2021.
}

Among many issues regarding the work and functioning of EU agencies, the termination of an agency is an important aspect to consider. The European Agency for Reconstruction (EAR), an EU agency that managed EU aid to the Western Balkans from 2001 to 2008, proved to be an efficient and effective agency in delivering aid. Although termination of any EU agency is a rare phenomenon, the EAR was terminated in 2008, despite its successful record. The termination of this highly successful agency stands as an example for the utility of putting termination theory into a larger framework of the existence of EU agencies, as scholarly literature has largely ignored the issue of termina-

* Islam Jusufi, Associate Professor of Political Science and International Relations, Epoka University, Tirana, Albania (izvanredni profesor politologije i međunarodnih odnosa, Sveučilište Epoka, Tirana, Albanija, email: islam.jusufi@gmail.com).

ORCID: https://orcid.org/0000-0003-0437-3819. 
tion in the work of the EU agencies. The EAR represented an institutional model of independence from politics and policy-making. The purpose of this paper is to assess the structure and operations of the EAR and reasons that led to its termination.

Keywords: EU, agencies, European Agency for Reconstruction, institutional termination, Western Balkans

\section{Introduction}

Nearly all EU member states host an EU agency that deals with issues related to acquis communautaire. Within this framework, agencies have played a significant role in European integration processes. The lifespan of $\mathrm{EU}$ agencies is an important aspect to consider, as various changes have been observed in their operations. The European Agency for Reconstruction (EAR), an EU agency that managed the EU aid to the Western Balkans from 2000 to 2008, proved to be an efficient and effective agency in delivering aid, considering the EU's cumbersome procedures for contracting and disbursement of aid. However, the EAR was terminated in 2008, despite its successful record.

The EAR represented an institutional model of independence from politics. The call by the European Commission (EC) for the integration of aid management with policy / politics with EC services or the European External Action Service won the argument for keeping aid away from policy-making bodies of the EU, leading to the termination of the EAR in 2008. Thus, it is important to consider the case of the EAR with respect to the institutional design it offered and the reasons why it was terminated. The specific circumstances which resulted in the termination of the EAR provide a unique learning tool. Significant resources for aid were allocated to the Western Balkans under the management of the EAR. The case of the EAR offers a rare institutional experience of the establishment, operations, and termination of an EU agency. This paper provides a picture of a comparative model of the EAR within the parameters of work of other EU agencies. As a result, it is important to consider the case of the death of the EAR, as it provides some interesting opportunities for learning.

At the time the EAR was in operation, the agency phenomenon within the scope of the EU was new, and was recognized and researched by scholarly literature in very limited ways. More recently, however, there has been an 
increase in efforts to document and analyse the emergence, the work and the design of EU agencies. In this light, the volume of important scholarly work on EU agencies has increased in recent years (Rittberger \& Wonka, 2011; Kreher, 1997; Busuioc, 2009). What is also worth considering is the emergence of different projects such as the Academic Research Network on Agencification of EU Executive Governance (TARN), and Agency Governance and its Challenges to the EU System of Representation, that have aimed to promote interdisciplinary research regarding the agencification of EU executive governance. However, the focus on termination of EU agencies is lacking in scholarly literature. While there have been studies on how the work of EU agencies has played out in various contexts, the number of studies focusing on their termination is still very limited.

This paper, therefore, focuses on the debate about the mission of the EAR, its institutional design and reasons for its termination. It tries to address a set of questions that occupy scholarly work in regard to EU agencies, by looking specifically at the case of the EAR: Why was the EAR established? What was its institutional design and governance? What does the EAR tell us about the endurance or life and death of EU agencies? This article investigates the trajectory of the EAR as a prime example to showcase the termination phenomenon in the lives of EU agencies.

\section{Overview of Literature, Theoretical Framework and Research Method}

The termination of EU agencies is a rare phenomenon. The literature in the field of international institutions has long asserted their resilience and endurance, despite the challenges to their existence (Eilstrup-Sangiovanni, 2021). However, the death of institutions, whether national or international, is a common occurence. Approximately $40 \%$ of international institutions, a category to which EU agencies broadly belong, have been terminated (Debre \& Dijkstra, 2021). The same has happened with institutions at national level across many European countries. Driven by this tendency, scholars of public administration have studied the termination phenomenon in the public sector since the 1970s (Lim, 2021). Termination is defined as "the deliberate conclusion or cessation of specific government functions, programs, policies, or organizations" (Daniels, 2001). Lately, the termination research has also been extended to include the study of the death of international institutions (Eilstrup-Sangiovanni, 2021; Debre \& Dijkstra, 2021). 
The termination literature has benefited greatly from the research that explained the causes of organizational termination, such as organizational adaptation (Boin et al., 2017), density dependence (Moldogaziev, Scott \& Greer, 2019), policy agenda (Mortensen \& Green-Pedersen, 2015), age (O'Leary, 2015), political ideology (deLeon, 1997), performance (Gilmour \& Lewis, 2006), size of the secretariat (Debre \& Dijkstra, 2021), exogenous factors such as geopolitical upheaval (Eilstrup-Sangiovanni, 2021), and new aid policies calling for the merger of aid management with the policy (Corbett \& Howard, 2017).

According to Corbett and Howard (2017), development policy has intrinsic value for the issue of termination as aid agencies across the world tend to share a tenuous existence. For example, the Australian aid agency (AusAID) was terminated in 2013. The Canadian International Development Agency (CIDA) was abolished in 2013, despite having existed since 1966, while the New Zealand's NZAID was terminated in 2009. The USAID has faced repeated termination attempts and has at various times had its functions integrated with the State Department. The most notable exception to this global trend is the UK's Department for International Development (DfID), which has managed to grow substantially in both size and autonomy in recent years. One reason for this tenuous existence is that foreign aid is a discretionary area of government spending, frequently with scarce domestic political support. That is, citizens want their government to give aid but they do not want them to give too much nor do they want foreign aid to be prioritized over domestic policy area. As a result, aid has proven to be a target during campaigns, thus becoming vulnerable for termination (Corbett \& Howard, 2017). The perpetually tenuous existence of aid is what makes the case of the EAR so valuable in debates about termination. Also, the contemporary risk of termination is fundamentally shaped by the "post-New Public Management" discourse, where political actors argue the importance of reasserting ministerial control and political accountability over the "organisational zoo" of inconsistent administrative arrangements left over from earlier era of specialisation and managerial devolution (Christensen \& Lègreid, 2005).

While many of these factors may account for the survival or death of international institutions, termination receives very little scrutiny in the framework of research on EU agencies. The aim of this article is to fill this gap by focusing on the case of the EAR. Although this is a study of a single case, it contributes to several avenues of research into the EU agencies and institutional termination. First, it contributes to insights regarding when and how international institutions die. Second, in doing so, it also helps refine the existing termination theories of why some institutions die. 
This article therefore asks why the EAR failed to survive, thereby contributing to the emergence of literature on the death of EU agencies.

The paper uses a qualitative method which can be best described as a process-tracing approach. The article was first developed on the basis of a review of available official documentation, reports, and scholarly publications. After collecting the initial data, an attempt was made to identify events and developments that related to the life and death of the EAR. The primary focus was on the timeframe of 2001-2008 in process-tracing of important aspects in the life of the EAR. This method also included participant observations, as the author was closely involved in following the developments regarding the closure of the EAR.

In order to explore the trajectory of the life and death of the EAR, the article firstly reviews its birth. Secondly, it looks to identify the EAR's institutional design. Following these discussions is an analysis of its performance and the process of its termination. The final section concludes with an analysis of the results seen in the case of the EAR, and examines the implications of the findings.

\section{The Birth of the European Agency for Reconstruction}

This section seeks to identify the factors which resulted in the establishment of EU agencies, and in this specific case the birth of the EAR. The existing literature focuses on structural factors and trends, such as the rise and growth of the regulatory state, functional imperatives which triggered the demand for independent agencies, as well as the role of inter-institutional politics and "power games" within the EU (Rittberger \& Wonka, 2011; Christensen \& Lègreid, 2005; Elgie \& McMenamin, 2005) as factors for the emergence of EU agencies. It also asserts that the agencies emerged to ensure that regulatory policy decisions and providing information for regulatory policy-making were appropriate for the purpose of insulating agencies from re-election-seeking politicians and instead leaving them in the hands of independent regulators who would adhere to professional considerations (Rittberger \& Wonka, 2011). From this perspective, the EAR can be considered an agency that sought to ensure the credibility and integrity of the EU in the field of aid management. Another perspective is to look at EU politics and inter-institutional strategic bargaining among member states, the EC, and the European Parlia- 
ment (EP) as a source of the emergence of EU agencies (Kelemen, 2002; Roederer-Rynning \& Daugbjerg, 2010), which can also be considered a reason for the establishment of the EAR.

Several different types of agencies have existed under the umbrella of the EU, including decentralised agencies, agencies under Common Security and Defence Policy, executive agencies, EURATOM agencies and bodies, among others (European Commission, 2008). The EAR was a sort of a decentralised agency which had a specific role, built upon its own legal basis of Council Regulation (2000b). In the categorisation of agencies developed by Kelemen (2002), the EAR falls within the category of neither information gathering agencies nor regulatory agencies. According to Pollak and Riekmann (2008), it was an executive agency. The EAR introduced a new management dimension and was an answer to the desire for geographical devolution and the need to cope with new tasks of technical nature. It operated as a subcontractor to the EC for the management of EU's aid (Pollak \& Riekmann, 2008). The EAR was entrusted with the task of distributing EU money throughout the former Yugoslavia and as such, it was a rare instance of actual transfers of powers from the EC to bureaucratic structures. The EAR was an exception in that it enjoyed budget implementation powers that are normally vested in the EC, according to the EC Treaty (Dehousse, 2008; Court of Justice of the EU, 2008; Korkea-aho, 2016).

The EAR was an independent body with its own legal personality and its own basic Council regulation (2000b), entrusted with the task and responsibility of managing and administering the EU aid to the Western Balkans Four or WB4 (Kosovo, Montenegro, North Macedonia, and Serbia). The EAR's raison d'itre was primarily to serve as a facilitator for the WB4 "on the road to Europe" (Bastian, 2008; Keane, 2005). The EAR as a decentralised agency was in charge of operational activities (European Commission, 2008). Therefore, the EAR as an operational and autonomous agency can be grouped under the category of decentralised agencies and may be considered a $1^{\text {st }}$ pillar agency based on the EC Treaty (Flinders, 2004).

Most agencies have an undetermined lifespan, with the exception of the EAR (and ENISA) which was established as a temporary agency for a limited period of nine years (2000 to 2008). The duration of the EAR's mandate was extended twice. The agency was continuously evaluated with the aim of reconsidering its mandate and even its very existence, first leading to a renewal of its mandate, followed by a change in the mandate, and finally its dissolution. Initially, it was established with a five-year mandate. 
Later, as the need arose, the initial five-year mandate was extended twice by the EU Council, first in 2004 and then in 2006, until the end of 2008 (Council of the EU, 2004, 2006; European Commission, 2004).

The EAR was established in February 2000 by the EU Council for the purpose of managing primary EU aid to the WB4 (Radeljić, 2014; Council of the EU, 2000b). Until 2000, EU aid to the WB4 was managed directly either by EC services in Brussels or by national authorities. It was the war in Kosovo that led to the establishment of the EAR in 2000, with the aim of assuming responsibility for the management of EU aid on the former Yugoslav territories (Nieminen, 2006; Tzifakis, 2013), including the aid dating back to 1997. Until the end of 2008, the EAR was principally responsible for the management of the CARDS national programmes in the WB4 (Grimm \& Mathis, 2015). The CARDS regional programmes were directly managed by the EC in Brussels. The EAR contracted the CARDS programme fully before its closure. Once the agency was closed, EU delegations took over the responsibility for managing and disbursing project activities.

In the 1990s, EU assistance to the Western Balkans was delivered through ECHO, PHARE, and OBNOVA programmes in order to enhance stability and prosperity in the region. ECHO provided humanitarian aid, OBNOVA provided assistance in reconstruction and rehabilitation, while PHARE focused on institutional building and cross-border cooperation. At the turn of the century, the CARDS programme was launched to focus on political, institutional and economic transition, and later, on EU convergence. Also, the EU provided macro-financial assistance in the form of balance of payments support to the region. As a response to the crises in the region, the EU also initialised the Emergency Response Programmes, which were designed to mitigate the consequences of the conflicts (Mace, 2004). The EAR took over the management of all these programmes, and kick started the implementation of the CARDS national programmes, and led to the planning of pre-accession assistance (Council of the EU, 2000a) under the title Instrument for Pre-Accession Assistance.

The EAR took over the work of the European Commission Task Force for Kosovo (Reliefweb, 1999) and subsequently expanded its activities to Serbia, Montenegro and then North Macedonia (Bastian, 2008; Council of the EU, 2001). It was designed as an instrument of support for the EU reconstruction efforts in Kosovo following the crisis in 1999, and the Emergency Assistance Programme in Serbia and Montenegro after the end of the Milosevic regime in 2000. The Feira European Council of June 2000 emphasised the EAR as an authority implementing the CARDS 
programme (European Council, 2000). Its mandate was then extended to North Macedonia in 2001 to support the implementation of the Ohrid Agreement, which brought an end to the conflict in the country (Council of the EU, 2001). Later, it was also entrusted with the implementation of assistance to encourage economic development of the Turkish Cypriot community (Council of the EU, 2006). However, the assistance to the Turkish Cypriot community in this capacity was never realised due to EAR's closure.

The EAR's aim was to support the reconstruction of damages incurred during the war in the WB4: rebuilding homes, power plants and power lines, hospitals and schools (Kovacs, Matopoulos \& Hayes, 2010; Minervini, 2002; Vrbensky, 2009). The regulation that established the EAR included its justification, but it did not sufficiently explain why new policy instruments had to be implemented through an agency, rather than other avenues. However, the reasons for establishing the EAR included the need to ensure the speed of aid delivery, to implement tasks in a framework of dialogue with local partners and beneficiaries, and to develop a specific plan to deliver targeted aid. Thus, the EAR was born as a response to these special circumstances and to the urgent need of post-conflict reconstruction of the WB4 (Chivvis, 2008; Tsoukalis, 1999). The EAR was designed to assist in the rehabilitation of the infrastructure and public utilities necessary to bring life back to normal for the people of the WB4 (Kilibarda, 2011; Kirchner, 2013). The contributions of the EAR to the post-war reconstruction of the former Yugoslav states that had been affected by the Kosovo war (Anastasakis, 2008) represented an aspect of the new approach that viewed the countries of the region as potential EU members (Friis \& Murphy, 2000).

All of the WB4 countries where EAR was present were involved in the wars that followed the breakup of Yugoslavia. In this light, the initial task of the EAR was to help the countries recover from the wars and conflicts that led to human suffering and substantial material damage. The EU determined that it should be a major player in helping stabilise and reconstruct the region following the conflicts (Greicevci, 2011). It was therefore seeking an effective and efficient way to deliver assistance to those territories. For post-crisis reconstruction, the most important criteria for success were to quickly calm ethnic tensions, bring aid to individuals most in need, and avoid misallocation and diversion of resources to opportunists (Bastian, 2008). This was a clear sign that the EC wanted to play a bigger role in the region (Stewart, 2008). Thus, setting up an agency such as the EAR in the host country or region was a result of lessons learned 
from the experience of heavy, inflexible bureaucracy and corruption, as was the case with EU aid to Bosnia (Friis\& Murphy, 2000). Therefore, procedures of the EAR had to be localised, flexible and very close to the field, acting as directly as possible with local partners, and making use of information and competence networks (Ramboll, 2009).

After the most critical reconstruction tasks were fulfilled, the EAR assisted in institutional reform, eventually supporting the European integration processes of the WB4. Thus, while remaining committed to its main task of delivering highly specific infrastructure reconstruction aid to WB4, its work changed gradually in response to the changes on the ground and changes in the context regarding the opening of the European integration perspective to WB4 (Ramboll, 2009). For implementing the assistance, it relied on the services of international and regional profit and non-profit organizations selected by specific tenders such as services, grants, twinning, supplies and works, as well as other modalities. The EAR was responsible for all phases of operations required to implement the aid programmes, including planning and preparation of annual assistance programmes, drawing up terms of references, preparing and evaluating invitations to tender, signing and awarding contracts, effecting payments, monitoring, and evaluation (Council of the EU, 2000b). The EAR was thus responsible for the full project cycle management. Although it had the mandate to implement aid programmes under the arrangements with EU Member States, other donors and international financial institutions (Council of the EU, 2000b), it rarely did so. Its main work was geared towards implementing EU aid. The total amount of EU aid managed by the EAR during its existence amounted to more than EUR 3 billion (Bastian, 2008; European Agency for Reconstruction, 2009). It is estimated that the agency had an annual budget of EUR 500 million, which funded everything from mine clearance, repair of infrastructure, environmental protection, and health care to energy supply (Buzar, 2008; Coker, 2003; Gorton et. al. 2010; Jednak et. al. 2009; Kumkar, 2003; Rexha \& Kopacek, 2010; Simićet. al. 2010; Supic et. al., 2010; Taleski, 2009). The support provided to the energy sector had a major impact, leading to record outputs from power stations, significant reductions in pollution, and a much more reliable and stable power supply system (Golusin, Tesic \& Ostojic, 2010). The bulk of the amount managed by the EAR was accounted for by the CARDS programme. Overall, the EAR was successful and efficient in delivering reconstruction assistance to the WB4. It was widely recognized by many as an efficient and flexible tool with a proven track record of delivering substantial assistance. 


\section{Institutional Design of the European Agency for Reconstruction}

This section intends to demonstrate that the EAR displayed a degree of formal-institutional independence. The EAR was an EU-level public authority with a legal personality and a certain degree of organisational and financial autonomy, established by a Council regulation for the purpose of delivering aid to the Western Balkans. Formally, the EAR was institutionally independent from its political principals - the EC, the EP, and member state governments in the Council (Wonka \& Rittberger, 2010), but was at the same time accountable to them. What were the determinants of the EAR's institutional design? It was designed to operate at arm's length from its political principals. By delegating competency and autonomy to the EAR and consequently restricting its possibility for direct political interventions, the EU designed the agency to send a strong signal of regulatory stability to countries benefiting from EU aid, asserting that a change in political majorities in the EU's legislative institutions, i.e. the EC, the EP and the Council, should not directly lead to an overhaul of decisions previously taken. In this way, it provided a credible commitment to the process (Wonka \& Rittberger, 2010). The EAR was thus provided with a degree of independence in order to contribute to its credibility and the expectations of beneficiaries in the WB4. It was not a regulatory agency, but having executive and operational tasks, it was designed to be less independent than similar agencies with regulatory tasks (Wonka \& Rittberger, 2010).

The EAR had a relatively high degree of formal autonomy and independence (Wonka \& Rittberger, 2010). Looking at the relationship between the EAR's autonomy and accountability (Busuioc, Curtin \& Groenleer, 2011; Curtin \& Egeberg, 2008; Egeberg \& Trondal, 2011), it is important to note that there was an understanding that it must be independent from the interference of the EC, the EP, and member states as its principals, so as to provide credible and unbiased aid. Also, it was often argued that the EAR must be held accountable for its actions in order to prevent it from abusing its powers with respect to the sensitive nature of the aid business. In the case of the EAR, autonomy and accountability were in balance, as its de jure and de facto autonomy coincided with the existence of a comprehensive framework of its de jure and de facto accountability. In fact, there was an accountability overload, as accountability practices were overblown in the case of the EAR. This happened in response to the fear on the part of the EC that the EAR may step into its politics, 
because of the power invested in the EAR as an aid managing authority. Despite overusing accountability measures, the EAR was able to establish close cooperation with the beneficiary governments and the EP specifically. The inter-institutional rivalry between the EP and the EC led to a situation where the EP became a champion of the EAR's work against the scepticism and suspicions of the EC. The EAR found itself much closer to the EP than to the EC, or to Council/member states (Egeberg \& Trondal, 2011). The overuse of accountability did not negatively impact the EAR's ability to act autonomously. The EAR is a case where the overuse of accountability mechanisms worked to the benefit of an agency's capacity to act autonomously. However, the EC felt that the EAR was detrimental to its position of the central executive actor (Curtin \& Egeberg, 2008).

The EAR had three political principals: the EC, the member states represented in the Council, and the EP. However, the EP did not have a say in the appointment of the EAR's governing board. Only the EC and the Council/member states had a say in this matter. This can be considered a weakness in the EAR's independence (Wonka \& Rittberger, 2010). But, being accountable to all three bodies opened room politically for the EAR to play the principals against one another when their preferences diverged regarding its closure. With respect to the continued existence of the EAR, cooperation with the EP, was "killed" when the then-director of the EAR, who held the title of an EC official, was appointed EU ambassador to the Democratic Republic of Congo. This act illustrated the limits of the independence of the EAR from the EC.

The choice of Thessaloniki, Greece as the seat and headquarters of the EAR was very relevant for its accountability to member states. Thessaloniki, Greece, was in close proximity to the region of Western Balkans and to the area in need (Friis \& Murphy, 2000). It lies approximately 80 $\mathrm{km}$ from the borders of the WB4. The initial proposal was to establish its headquarters in Pristina (Friis \& Murphy, 2000). The decision to choose Thessaloniki was the result of a compromise concerning the appointment of envoys of EU member states to various EU agencies. Greece had lost the battle for the appointment to head the Stability Pact for Southeast Europe to Germany. This move prompted Greece to insist that the seat of the EAR be located there. The result was that Greece as a member state became the headquarters of the EAR (Friis \& Murphy, 2000).

Besides its general services located in Thessaloniki, the EAR established Operational Centres with a considerable degree of management autonomy. It had four operational centres in the WB4 capitals of Belgrade (Serbia), Podgorica (Montenegro), Pristina (Kosovo), and Skopje (North 
Macedonia). Operational centres were a result of a lesson learned from the ineffective operation of a top-down approach centred in Brussels, and it had to be complemented by a bottom-up local/regional approach (Bastian, 2008). The EAR showed why a remote, top-down approach centred in Brussels did not and could not work as effectively as when complemented by a regional presence (Georgiadis, 2008) and community-based approach (Kovacs, Matopoulos \& Hayes, 2010).

The EAR was overseen by a Governing Board responsible for ensuring that it performed the tasks that had been set out from its inception. The Board was composed of one representative from each Member State and two representatives from the EC with full voting rights, plus an observer from the European Investment Bank, who did not have voting rights (Council of the EU, 2000b). Member States' representatives on the board were rather passive, with only few exceptions. Their presence was, for the most part, a security procedure for avoiding major disagreements about the EAR's actions with member state prerogatives and priorities. This compelled the EAR to reach consensus by preliminary consultation prior to board meetings.

The EAR was headed by the director responsible for its overall operation. The director was appointed by the Board for a term of 30 months. The agency's director was nominated through a process involving both the EC and the Board. The first director of the EAR was Hugues Mingarelli, who held the post of Director from 2000 until 2002. His successor was Richard Zink, who held the position from 2002 until 2007. The successor of Director Zink was Adriano Martins, who held the post as Acting Director until the closure of the agency in 2008. All the directors were EC officials. Each operational centre, established by the Governing Board, had its own head, appointed by the Director. The EAR had sufficient flexibility to manage its human and financial resources efficiently (Ramboll, 2009). The Agency's staff consisted of a strictly limited number of officials assigned or seconded by the EC to carry out management duties. The remaining staff consisted of other employees recruited by the EAR for a period strictly limited to its requirements. The total number of staff in the EAR was 312, 114 of which were temporary agents and 198 were local agents, all paid by the operational aid budget lines.

The EAR was funded by the EU budget, more precisely by the aid budget. Therefore, it was funded by money from the aid budget allocated to countries under the CARDS programme. The framework financial regulation laid down common rules governing the implementation of the EAR 
budget, including control aspects. It received budgetary discharge directly from the EP as the budgetary authority. On a recommendation from the Council, the EP gave a discharge to the Director in respect to the implementation of the Agency's budget (Council of the EU, 2000b). The discharge was always given to the EAR by the EP, either with or without comments.

External control lay with the EU Court of Auditors, which examined the accounts and published an annual report on the EAR's activities. The main and most frequent problems highlighted in the annual reports were related to procurement procedures, recruitment, and carryover of appropriations. The Court of Auditors specifically assessed that the EAR's form showed greater efficiency compared to other forms of aid management, due to the quality of devolved and indirectly centralised action. The EAR was also subject to regular visits by the EC's Internal Audit Service, which played the role of an internal auditor for the agency.

The work of the EAR regularly underwent internal monitoring, as well as both internal and external evaluations. Two types of internal evaluations were undertaken by the EAR: overall evaluations and evaluations of specific activities. Periodic overall evaluations contributed to improving the transparency of the agency. The EAR self-evaluated its activities on a regular basis. Separately, the EC also conducted independent external evaluations on the work of the EAR.

Performance information related to the EAR's responsibility in achieving its intended outputs and results was documented and continuously published on the agency's website. Unfortunately, the website was not maintained and consequently no longer exists, despite rich information that was made available. The EAR ran an intranet and internet system which enabled it to monitor and publish its contracting and disbursement amounts and rates on a daily basis. Performance reporting in the form of quarterly and annual reports served as a basis for the discharge procedure. The discharge procedure was limited to regularity. The EP made its decisions on the grounds of the agency's accounts and reports, statements of assurance and reports made by the Court of Auditors, hearings of the Director and Director's answers to written questions.

The institutional design of the EAR as described above was a model specific to it and took into account political considerations of various factors such as the EC, the EP, and member states, whose politics later subsequently led to the closure of the EAR. See Figure 1 summarising the EAR's institutional design. 
Figure 1: Institutional design of EAR

Independent but accountable to EC, EP and member states

EAR's Institutinoal

Design

Led by Director and overseen by Governing Board
Extensive field presence with Operational Centres in WB4 and headquarters in Thessaloniki

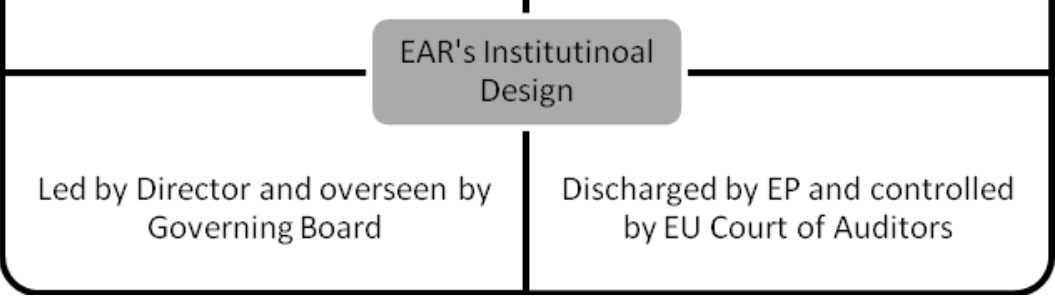

Source: Author.

\section{The Performance of the European Agency for Reconstruction}

There was a clear need for the EAR and it became an effective tool in implementing EU policies. It delivered EU aid to the WB4, making it a key player in the implementation of EU policies towards the WB4 as a part of the EU's Stabilisation and Association Process towards the Western Balkan region as a whole. In this framework, the EAR made a significant and useful contribution to the effective operation of the EU in the WB4. It also contributed to implementing EU policies in a more direct manner by providing highly specialised services. The agency also mobilised expertise in aid management, and built up highly respected technical and specialist know-how, which helped the EU deliver results with speed and effectiveness (Cameron \&Kintis, 2001). It pooled technical and specialist expertise from EU member states and beneficiary countries. It helped disburse the EU's aid more effectively, thus serving the interests of the EU in the WB4. As a consequence, the EC was in a position to concentrate on its core task of policy making. The EAR added to the visibility of the EU in the region. For many people living within the WB4, the EAR was the closest visible presence of the EU in their lives. The EAR proved particularly relevant in the field of aid management, as the implementation of aid to the WB4 required close cooperation between the EU and the beneficiary countries. The agency played a role in helping the WB4 become more familiar with the EU and with the EU acquis and best practices. Its mission was effective and efficient delivery of EC assistance programmes, thereby 
helping the governments with the process of integration to the European Union. There is clear evidence that the EAR achieved the planned outputs, as seen in its activity reports and in internal monitoring and evaluation reports (European Agency for Reconstruction, 2008), and also in the external evaluations conducted by the EC (Ramboll, 2009; Particip $\mathrm{GmbH}, 2009$ ).

The activities of the agency were in compliance with its mandates. Its approach was cooperative and inclusive. Complementarities and coherence with EU policies and other donors were generally maintained on a more continuous basis throughout the EAR's programmes (Presnall, 2009). The programmes were usually subjected to extensive consultation with parent Directorate Generals of the EC, and often also with other relevant EC services and agencies. Coherence was greatly enhanced as the EAR served a specific EU policy: aid management to the WB4. To ensure ownership and effectiveness of the assistance, it developed and implemented programmes through an on-going dialogue with the beneficiary institutions, the ultimate goal being to increase the absorption capacity of the governments. Assistance programmes sought synergies and complementarity with the activities of other donors and therefore promoted open and close coordination, in particular with EU Member States and with international financial institutions. Today's donor coordination mechanisms in the WB4 are the legacies of the assistance and policy advice of the EAR. In addition to its parent DG (External Relations), the EAR was systematically consulting with other relevant DGs, in consideration of political issues of the policy implemented. For instance, policing in Skopje was an important issue, so the agency organised meetings with the Council and the DG JLS. DG AGRI was also an important DG and a committee was established to work with the agency and to interact on a regular basis. Links with CEDEFOP and the World Bank were also reported (Ramboll, 2009). Sharing roles with the EC appeared very clear. The EC produced multi-annual plans for intervention in the countries, drafting the "country strategy" that identified priorities for intervention and objectives to be met. Interestingly, these guidance documents were assessed as too general for proper direction of EU action by the Court of Auditors, whereas the EAR seemed to have found them sufficient and helpful (Ramboll, 2009). This could indicate that the EAR was able to efficiently complement the EC's general vision with field specificity and technical sectoral relevance (Ramboll, 2009).

The EAR-managed EU funded programmes reflected the priorities of the EC's 2002-2006 Country Strategy Papers and the Multi-annual Indicative 
Programmes of the periods 2002-4 and 2005-6 (European Commission, 2002). The EAR sought to reinforce the priorities of the Stabilisation and Association Agreements, EC annual progress reports, EC Opinions on the countries' applications for membership of the EU, including the Analytical Reports for the Opinions, and the European/Accession Partnership - important documents that outlined main priorities required for further integration of Western Balkan countries into the EU and served as the key documents that have guided the region's accession process. The European Partnership and later Accession Partnership identified priorities for action, which served as signposts for the EAR's initiatives on the field. These documents were the key to the countries' economic and social reform agenda, as well as their rapprochement toward European structures. The major political developments in the WB4 during the EAR mandate were applications for EU membership, signing and ratification of the Stabilisation and Association Agreements, preparations for awarding visa-free entry to the Schengen Zone, and awarding candidate status. In this context, the EAR supported the WB4 in efforts to honour their commitments to meet these important benchmarks in the EU accession process. The Agency specifically helped the WB4 to move forward particular priorities highlighted in the European/Accession Partnership, as a means for the countries' realisation of their European integration perspective. Thus, the EAR's overall work was geared towards helping the countries fulfil the key requirements of the integration process for accession to the $\mathrm{EU}$, in particular the alignment of national legislation with EU acquis communautaire. This assistance was coupled with strong elements of institution and capacity building that strengthened the capability of national institutions in meeting demands of the overall integration process. With its projects in various fields, the EAR had an impact by supporting key institutions, laws and practices. In this context, the agency, with projects covering various fields, worked on capacity building, training, raising awareness, establishing and restructuring state bodies and other actors. The EU via the EAR delivered substantial support to the WB4 in terms of their legal, social, and economic development. The aim of all projects supported by the agency was strengthening the capacity of relevant state institutions, private sector, media and civil society organizations by giving them the ability to establish necessary platforms to increase awareness, developing close links with the government and providing expertise on major issues (Fagan, 2011; Radovic \& Luther, 2012; Tenner, 2010).

As the EU's main assistance management institution in the WB4, the EAR was successful and efficient in delivering substantial assistance to the WB4. 
Just after the agency's establishment, funds were spent at a rate of $80 \%$ a year, which was very satisfying considering the contextual constraints (European Court of Auditors, 2001). Provided support ranged from technical assistance to works and supplies. A number of projects were implemented with twinning arrangements and grant schemes. In practical terms, support consisted of advisory support, legislative development, organisational development, material support, training, and support to operational implementation. Support covered a broad spectrum from organisational and administrative reform to operational and educational support across various sectors, ranging from political priorities and economic issues to acquis-related issues (Jusufi, 2018). The overall work of the EAR's programmes established the fundamentals for work in the WB4 regarding reconstruction, democratisation, and European integration of the region. The EAR witnessed the progress achieved by the countries, including building necessary legislative bases, establishment of institutions, institution and capacity building, and enrichment of civil society and private sector. The agency was a major reference point for changes seen in the WB4. However, it did not produce results on its own. The aid combined with EU policy conditionality supported the change. The observed changes were also dependent on the readiness of the beneficiary countries themselves and their actors and institutions. Thus, it was a combination of aid, conditionality and readiness of the local actors that brought about the changes.

The first and last reports of the Court of Auditors (2001 and 2007, respectively) stated that the EAR met its objectives. The first report stated that the "outstanding performance" of the EAR was due to its focus on a limited number of priority areas. It also assessed that the high rate of budget implementation accompanied by results achieved in lowering prices and supporting local activities, thus helping the recovery of local economies, which also involved risks for the EAR. Establishing the agency was seen in retrospect as an efficient way to significantly improve the EU's action in this field. Referring specifically to the establishment of the EAR, the Court of Auditors stated that the EU's assistance helped normalise life in Kosovo (European Court of Auditors, 2001). However, the consistency of the agency's activities and its objectives was questioned in respect to the shifting of institutional support. For instance, the Court of Auditors reports that the EAR used the full amount of funding for the border control reinforcement programme instead of purchasing vehicles (European Court of Auditors, 2007; Collantes-Celador \& Juncos, 2012; Grillot, 2010; Ryan, 2009). The Court of Auditors' draft suggests that redirecting the action of an agency established for a specific purpose is 
not easily done and may potentially lead to inefficiency. In addition to the fulfilment of reconstruction mission and mandate, the reports submitted by the EAR to EU institutions were overall considered to be of high quality. The Court of Auditors recommended that the EC delegations use EAR monitoring reports as a standard for delegation reports. Likewise, quarterly reporting was also praised for its quality (European Court of Auditors, 2007).

Being de-centralised, the EAR could avoid some of the drawbacks of the EU system, and especially some of its administrative burdens. Efficiency was assessed as satisfactory, resulting from implementation mechanisms such as field-based detailed identification of the specific type of assistance needed prior to any grant or aid provided, or competition among providers of construction materials through large framework contracts and tenders organised per type of materials, careful ex-ante selection of enterprises, and implementation through a voucher system. This reduced costs by helping focus aid on priority needs. The agency was also praised for its well-designed and consistent monitoring practices, as acknowledged by the Court of Auditors, which clearly recommended that its methodology for project evaluation and monitoring be extended to the EU delegations (European Court of Auditors, 2007).

According to external evaluation conducted by the EC, the story of the EAR is one of success in terms of performance in delivering highly specific services in the context of EU external policy (Ramboll, 2009). In a separate external evaluation, it was assessed that the agency met the priorities identified in the EC Country Strategy Papers, national strategies, project fiches and the Stabilisation and Association Process. Furthermore, the same external evaluations determined that interventions conducted by the EAR had a number of important positive impacts on government policy, institutions, private entities and individuals. In the evaluation, weaknesses were identified in relation to limited involvement of national stakeholders and target groups in the needs assessment and project design (Particip, 2009).

In general, a question of concern was whether the EAR could rise to the challenge. Despite initial misgivings, EU institutions were reassured primarily due to rapid delivery of assistance. With a strong record of planning, contracting, and disbursing the available funds, the EAR was recognized by observers as successful and efficient in delivering reconstruction assistance in the WB4, and was considered an efficient and flexible tool with a track record of delivering substantial assistance (European Agency for Reconstruction, 2007). 


\section{The Reasons for Closure of the European Agency for Reconstruction}

Unlike other decentralised or regulatory agencies, the EAR was established as a temporary body, not for an indefinite period, but for a limited period of time. When it was founded in 2000, the duration of its mandate was stipulated for five years. The EAR's founding regulation (Council of the EU, 2000b) foresaw an end date by which the agency's mandate would expire. Its founding regulation called for a review clause allowing for an assessment as to whether the agency had fulfilled its mandate before being disbanded. Its founding regulation stated that the EC should submit a proposal to the Council to wind up the agency once the EC considered that the agency had fulfilled its mandate. It also foresaw the need for an evaluation report prepared by the EC together with a proposal on the status of the agency.

Before the end of its mandate, the EC prepared evaluation reports for the purpose of determining whether or not the duration of the EAR should be extended beyond the above-mentioned period in 2004 and again in 2005. The evaluation assessed the impact of the agency on achieving its objectives and tasks, as well as its working practices and proposed the termination of the EAR.

The first evaluation report was submitted in July 2004, proposing an extension of additional two years, through 2006. The founding regulation was amended to include the proposed extension. Another evaluation report was submitted to the Council and to the EP on 23 December 2005. On that basis, the EC submitted a proposal to extend the mandate of the EAR for additional two years in April 2006, ending on 31 December 2008 and to gradually phase out its activities under CARDS. The extension of the EAR's mandate was granted for the purpose of allowing the agency to finalise the CARDS programmes it was managing at the time. The main objective as stated was to enable the continuation of aid delivery without disruptions, with the best possible efficiency and in a cost-effective manner (Council of the EU, 2006). According to the EC, the progressive phasing-out of the EAR was to be completed by 31 December 2008, and concurrent establishment of de-concentrated delegations would make the EU presence more transparent and more efficient. These delegations would also assume responsibility for the implementation of CARDS' successor assistance programme and the Instrument for Pre-Accession Assistance. The two-year extension of the mandate was intended to allow for a 
transfer of responsibilities from the EAR to the EC services, in particular to its Delegations in an orderly manner (Council of the EU, 2006). This paved the way for the EAR to close the contracts with all CARDS projects and make substantial progress in implementation of the already contracted projects. The files that were transferred to the EU Delegations included files of the already contracted projects which required implementation beyond 2008.

When proposing the closure of the EAR, the EC argued for the need of closer link between the political process under the Stabilization and Association Process and financial assistance, all the way to the future accession of the WB4. In this direction, it argued that aid management should move from the EAR to the WB4, from centralised to decentralised management, as the WB4 needed to assume their own financial responsibility for the implementation of EU assistance by progressively moving towards decentralised implementation systems. The result would force responsibility for the programme preparation and implementation to rely primarily on the national institutions, first under scrutiny (ex-ante control) of the EC, and finally fully under their individual national control. Another reason given was the need to be coherent with respect to aid management in all Western Balkan countries as other potential candidates. Several candidate countries of the Western Balkans such as Albania, Croatia, and Bosnia and Herzegovina, were not beneficiaries of the EAR assistance (Hills, 2004). EU assistance to these countries was either managed directly by the EC in Brussels, or by decentralised institutions of national authorities. The EAR worked only in Kosovo, Macedonia, Montenegro, and Serbia, while EC assistance in the other aforementioned countries (Croatia, Bosnia and Herzegovina, and Albania) was implemented in a directly centralised, yet deconcentrated manner through the EC Delegations. The EC later accredited national authorities to manage assistance in a decentralised manner (Council of the EU, 2000a).

According to the EC, there was no reason for this differentiation between EAR-managed and EC-managed aid to be maintained in light of preparations for future membership. For the EC, maintaining the EAR would have led to a challenge to justify differentiation between the countries and would send blurred signals to the countries in the region. The goal was first to move to a deconcentrated management mode where EU delegations manage assistance. The ultimate goal was to move toward de-centralisation where national administrations of beneficiary countries would manage assistance by themselves. For the EC, the decentralised model has been an efficient way to assist the beneficiary countries on their road 
to accession by progressively integrating them into EU policies and by teaching them to manage EU financial aid in an autonomous way, as an integral part of the preparations for their future participation in structural, cohesion and rural development funds after the accession (Council of the EU, 2006). For the EC, a single interlocutor, through de-concentrated delegations to implement the acquis and manage aid, had important advantages (Council of the EU, 2006).

The EAR was dissolved with political purpose of providing a degree of uniformity in the treatment of each country in the Western Balkan region, so that they could gradually meet their financial responsibilities in implementing EU financial assistance in a decentralised fashion. According to the EC, the purpose of the transfer of responsibilities for the management of pre-accession instruments to EC delegations (de-concentration) and national authorities (de-centralisation) was to enable applicant and potential applicant countries to become familiar with the management of structural funds prior to their accession (Council of the EU, 2006). However, according to the EC, the EAR could not promote such a process because of an indirect centralised manner in which it managed EU funds.

The EAR was dismantled by means of a legal act amending its founding act. In April 2006, the EC presented a proposal for a regulation extending the Agency's mandate until 31 December 2008, after which its activities would be terminated. With that date, the EAR was disbanded. The agency was able to complete the management of funds allocated to these countries under the CARDS programme. Ongoing programmes were transferred to the EC and the management of community aid was gradually transferred to EC delegations. The delegations in Belgrade, Podgorica, Skopje and Pristina were upgraded in order to be able to provide continuation of aid management.

The EAR was closed as it had fulfilled its tasks, thereby eliminating the very needs which composed its rationale. According to external evaluation, the EAR was closed after having achieved its goals (Ramboll, 2009). This can be viewed as a positive ending of a success story. But reports show that some EP members recommended the continuation of the agency for use in other post-crisis interventions (Palestine, Afghanistan, etc.), while other EP members and EC authorities preferred the option to close. The relevance of this decision was then based on the actual ability of delegations to take over indispensable tasks, or on considering the remaining tasks manageable for a delegation in addition to its current activities (Ramboll, 2009). The EP officially decried the fact that an efficiently 
functioning agency was abolished and the management of funding was transferred to delegations (European Parliament, 2010)

In retrospect, an executive agency would probably have been more relevant in the context of the Balkans, but legal provisions for such agencies were not available at the time. Reconstruction tasks were new and not transferred. For subsequent missions in the field of institutional reforms support, the EAR was probably acting as a precursor of the EC when pre-accession aid and support to these countries entered into the scope of the EC (Ramboll, 2009).

User satisfaction with the services provided by the EAR was positive, with the exception of government stakeholders who held posts in the institutions that were supposed to manage EU funds, like the ministries or secretariats for European integration, or central financing and contracting departments of the ministries of finance.

The actual dissolution of the EAR (staff contracts and liquidation of assets) was a task for the EAR itself. Necessary decisions were adopted by the Director and the Governing Board of the agency, according to their respective powers. Detailed arrangements for the actual transfer of files and archives to EC services were agreed to in a timely manner by an administrative arrangement between EC services and the Director of the EAR. The phasing out of the agency was accompanied by an equivalent phasing in of the implementation of Community assistance in a de-concentrated way by EC Delegations in the countries concerned (Particip GmbH, 2009).

Looking at the reasons for closure of the EAR based on a dual strategy of state-building and European integration, the EU sought political aims in replacing other international organisations in the post-conflict reconstruction of the Western Balkans (Bieber, 2011). The EC looked to the EAR to function only as an EU aid manager in the Western Balkans and did not provide for a broader vision of its position in the Union's overall aid management in the Third World. The EAR could have been maintained and asked to manage the EU aid in other parts of the world, including Eastern Europe, the Caucasus, Central Asia, the Middle East, Africa, and in other places where needed. The narrow vision made it difficult for the EC to benefit effectively from the EAR. The quality and usability of EAR products and services were generally perceived as good by the EC, but were seen as a direct threat to the EC's capacity to maintain its core task of managing EU aid.

The EAR represented an institutional model of independence from politics and policy-making. The EU had overall responsibility for the policy, 
but the EAR served as a separate executing agency responsible for implementation of the aid (Gavas, Gulrajami \& Hart, 2015). The call by the EC for integration of aid management with the policy/politics within EC services won the argument against keeping aid away from the EU policy bodies, leading to the closure of the EAR in 2008. The new model consisted of the EC becoming responsible for both policy and implementation in aid management (Gavas, Gulrajami \& Hart, 2015). It reflected the emerging global view that aid should serve broader policy objectives (Corbett \& Dinnen, 2016). This new political discourse requiring greater coherence between aid and diplomacy represented a considerable threat to the existence of the EAR that actually led to its termination. According to the "new aid paradigm", aid and foreign policy objectives would be better aligned, winning over the argument that separate agencies are indeed better in delivering aid.

\section{Conclusion}

In this paper, the author provided an analysis of the reasons for the establishment, closure, and termination of the EAR as an EU agency. The EAR as an EU agency operating in the field of aid management showed some level of independence. The evidence found is that, as the aid was politicised, this led to the de facto independence of the EAR. While the EAR had autonomy and independence, the way it was designed guaranteed the Council and the EC an important role in the direct control of how the agency performed its tasks, in order to make sure that it serves EC political goals.

The EAR brought real added value to the EU's aid delivery. However, the potential of the EAR was held back by the new aid paradigm in combining aid with wider policy and political objectives, leading to its termination. Nevertheless, EAR legacy remains highly relevant in the years to come for the research of survival and termination of EU agencies.

The EAR's termination story provides an important contribution for research of institutional termination. Its institutional design allowing for control by the principals or performance did not ensure its survival; a new aid policy agenda emerged as a result of new geopolitical changes occurring around the world, contributing to its termination. Theoretically, this is important because it shows that contextual, political and policy changes can contribute to the death of institutions. The EU sought political aim 
in replacing other international organisations in the post-conflict reconstruction of the Western Balkans by strengthening its political arm, and existence of the EAR was not perceived as contributive to this new political vision of the EU.

This article has sought to contribute to the emergence of empirical foundations for researching institutional terminations in the case of EU agencies. Given that deaths of EU agencies are a rare phenomenon and that it is an aspect that is understudied, this article has combined termination research with a focused case study to establish empirical grounds for analysis. It demonstrates the further need to focus on exogenous factors as they can undermine the functioning of institutions and lead to their termination.

\section{References}

Anastasakis, O. (2008). The EU's Political Conditionality in the Western Balkans: Towards a More Pragmatic Approach. Southeast European and Black Sea Studies, 8(4), 365-377, https://doi.org/10.1080/14683850802556384

Bastian, J. (2008). "Cry Wolf No More: External Anchors and Internal Dynamics in the Western Balkans. Southeast European and Black Sea Studies, 8(4), 325-344, https://doi.org/10.1080/14683850802556368

Bieber, B. (2011). Building Impossible States? State-Building Strategies and EU Membership in the Western Balkans. Europe-Asia Studies, 63(10), 1783-1802, https://doi.org/10.1080/09668136.2011.618679

Boin, A., Kofman, C., Kuliman, J., Kuipers, S., \& van Witteloostujin, A. (2017). Does Organizational Adaptation Really Matter? How Mission Change Affects the Survival of US Federal Independent Agencies. Governance, 30(4), 663-686, https://doi.org/10.1111/gove.12249

Busuioc, M., Curtin, D., \& Groenleer, M. (2011). Agency Growth Between Autonomy and Accountability: The European Police Office as a "Living Institution”. Journal of European Public Policy, 18(6), 848-867, https://doi.org/10.10 80/13501763.2011.593313

Busuioc, M. (2009). Accountability, Control and Independence: The Case of European Agencies. European Law Journal, 15(5), 599-615, https://doi. org/10.1111/j.1468-0386.2009.00480.x

Buzar, S. (2008). Energy, Environment and International Financial Institutions: The EBRD's ctivities in the Western Balkans. Geografiska Annaler: Series B, Human Geography, 90(4), 409-431, https://doi.org/10.1111/j.14680467.2008.00301.x

Cameron, F., \& Kintis, A. (2001). Southeast Europe and the European Union. Southeast European and Black Sea Studies, 1(2), 94-112, https://doi.org/ $10.1080 / 14683850108454640$ 
Chivvis, C. S. (2008). The Making of Macedonia. Survival: Global Politics and Strategy, 50(2), 141-162, https://doi.org/10.1080/00396330802034275

Christensen, T., \& Lègreid, P. (2005). Regulatory Agencies - The Challenges of Balancing Agency Autonomy and Political Control. Governance, 20(3), 499_ 520, https://doi.org/10.1111/j.1468-0491.2007.00368.x

Coker, C. (2003). Empires in Conflict: The Growing Rift Between Europe and the United States. Responsibility. Whitehall paper series 58. London, UK: Royal United Services Institute for Defence and Security Studies.

Collantes-Celador, G., \& Juncos, A. (2012). The EU and Border Management in the Western Balkans: Preparing for European Integration or Safeguarding EU External Borders? Southeast European and Black Sea Studies, 12(2), 201220, https://doi.org/10.1080/14683857.2012.686250

Corbett, J., \& Dinnen, S. (2016). Examining Recent Shifts in Australia's Foreign Aid Policy: New Paradigm or More Incremental Change? Australian Journal of International Affairs, 70(1), 87-103, https://doi.org/10.1080/10357718.201 5.1085955

Corbett, J., \& Howard, C. (2017). Why Perceived Size Matters for Agency Termination. Public Administration, 95(1), 196-213, https://doi.org/10.1111/padm.12299

Council of the EU (2006). Council Regulation 1756/2006 of 28 November 2006 amending Regulation (EC) No 2667/2000 on the European Agency for Reconstruction.

Council of the EU (2004). Council Regulation 2068/2004 of 29 November 2004 amending Regulation (EC) No 2667/2000 on the European Agency for Reconstruction. Brussels.

Council of the EU (2001). Council Regulation 2415/2001 of 10 December 2001 amending Regulation 2666/2000 on assistance for Albania, Bosnia and Herzegovina, Croatia, the Federal Republic of Yugoslavia and the Former Yugoslav Republic of Macedonia and Regulation 2667/2000 on the European Agency for Reconstruction. Brussels.

Council of the EU (2000a). Council Regulation 2666/2000 of 5 December 2000 on assistance for Albania, Bosnia and Herzegovina, Croatia, the Federal Republic of Yugoslavia and the Former Yugoslav Republic of Macedonia. Brussels.

Council of the EU (2000b). Council Regulation 2667/2000 of 5 December 2000 on the European Agency for Reconstruction. Brussels.

Court of Justice of the EU (2008). Case T-411/06. Sogelma-Societá Generale Lavori Manutenzioni Appalti Srl v. European Agency for Reconstruction. ECR II-2771.

Curtin, D., \& Egeberg, M. (2008). Tradition and Innovation. Europe's Accumulated Executive Order. West European Politics, 31(4), 639-61, https://doi. org/10.1080/01402380801905868

Daniels, M. R. (2001). Policy and Organizational Termination. International Journal of Public Administration, 24(3), 249-262, https://doi.org/10.1081/PAD100000447 
Debre, M. J., \& Dijkstra, H. (2021). Institutional Design for a Post-Liberal Order: Why Some International Organizations Live Longer Than Others. European Journal of International Relations, 27(1), 311-339, https://doi. org/10.1177\%2F1354066120962183

Dehousse, R. (2008). Delegation of Powers in the European Union: The Need for a Multi-Principals Model. West European Politics, 31(4), 789-805, https://doi. org/10.1080/01402380801906072

deLeon, P. (1997). Afterward: The Once and Future State of Policy Termination. International Journal of Public Administration, 20(12), 2195-2212, https://doi. org/10.1080/01900699708525292

Egeberg, M., \& Trondal, J. (2011). EU-Level Agencies: New Executive Centre Formation or Vehicles for National Control? Journal of European Public Policy, 18(6), 868-887, https://doi.org/10.1080/13501763.2011.593314

Eilstrup-Sangiovanni, M. (2021). What Kills International Organisations? When and Why International Organisations Terminate. European Journal of International Relations, 27(1), 281-310, https://doi.org/10.1177\%2F1354066120932976

Elgie, R., \& McMenamin, I. (2005). Credible Commitment, Political Uncertainty or Policy Complexity? Explaining Variations in the Independence of NonMajoritarian Institutions in France. British Journal of Political Science, 35(3), 531-48, https://doi.org/10.1017/S0007123405000281

European Agency for Reconstruction (2009). Annual Report 2008. Thessaloniki. Retrieved from https://web.archive.org/web/20060619074253/http://ear.europa.eu/home/default.htm

European Agency for Reconstruction (2008). Annual Report 2007. Thessaloniki. Retrieved from https://web.archive.org/web/20060619074253/http://ear.europa.eu/home/default.htm.

European Agency for Reconstruction (2007). Annual Report 2006. Thessaloniki. Retrieved from https://web.archive.org/web/20060619074253/http://ear.europa.eu/home/default.htm

European Commission (2008). European agencies - The way forward. Brussels. Retrieved from https://ec.europa.eu/commission/presscorner/detail/en/ MEMO_08_159.

European Commission (2004). Evaluation of the assistance to Balkan countries under CARDS regulation 2666/2000. Brussels. Retrieved from http://docplayer. net/137201958-Evaluation-of-the-assistance-to-balkan-countries-under-cards-regulation-2666-2000-synthesis-report-volume-iii-annexes-june-2004.html

European Commission (2002). CARDS Assistance Programme to the Western Balkans, Regional Strategy Paper 2002-2006 with Multi Annual Indicative Programme 2002-2004. Brussels. Retrieved from https://reliefweb.int/report/ albania/cards-assistance-programme-western-balkans-regional-strategy-paper-2002-2006

European Council (2000). Feira European Council, 19-20 June 2000. Conclusions of the presidency. Retrieved from https:/www.europarl.europa.eu/summits/fei1_en.htm 
European Court of Auditors (2007). Report on the Commission's Management of the CARDS programme together with the Commission's replies (2007/C 285/01). Brussels. Retrieved from https://eur-lex.europa.eu/legal-content/EN/ TXT/?uri=OJ\%3AC\%3A2007\%3A285\%3ATOC

European Court of Auditors (2001). Report concerning the financial accounts of the European Agency for reconstruction and the implementation of aid for Kosovo for the year 2000, accompanied by the replies of the Commission and of the European Agency for Reconstruction (2001/C 355/01). Brussels. Retrieved from https://eur-lex.europa.eu/legal-content/SL/ ALL/?uri=CELEX:52001TA1213(01)

European Parliament (2010). Discharge: European Agency for Reconstruction. European Parliament decision of 5 May 2010 on discharge in respect of the implementation of the budget of the European Agency for Reconstruction for the financial year 2008. Retrieved from https://eur-lex.europa.eu/legal-content/EN/ALL/?uri=CELEX:32010B0514

Fagan, A. (2011). EU Assistance for Civil Society in Kosovo: A Step Too Far for Democracy Promotion? Democratization, 18(3), 707-730, https://doi.org/10. 1080/13510347.2011.563119

Flinders, M. (2004). Distributed Public Governance in the European Union. Journal of European Public Policy, 11(3), 520-544, https://doi.org/10.1080/13501 760410001694282

Friis, L., \& Murphy, A. (2000). Turbo-Charged Negotiations: The EU and the Stability Pact for South Eastern Europe. Journal of European Public Policy, 7(5), 767-786, https://doi.org/10.1080/13501760010014948

Gavas, M., Gulrajani, N., \& Hart, T. (2015). Designing the Development Agency of the Future. Framing paper. London, UK: Overseas Development Institute.

Georgiadis, G. G. (2008). The Convergence-Divergence Debate Revisited: Framing the Issues. Southeast European and Black Sea Studies, 8(4), 313-323, https://doi.org/10.1080/14683850802556343

Gilmour, J. B., \&Lewis, D. E. (2006). Assessing Performance Budgeting at OMB: The Influence of Politics, Performance, and Program Size. Journal of Public Administration Research and Theory, 16(2), 169-186, https://doi.org/10.1093/ jopart/muj002

Golusin, M., Tesic, Z., \& Ostojic, A. (2010). The Analysis of the Renewable Energy Production Sector in Serbia. Renewable and Sustainable Energy Reviews, 14(5), 1477-1483, https://doi.org/10.1016/j.rser.2010.01.012

Gorton, M., Lowe, P, Quarrie, S., \& Zarić, V. (2010). European Rule Adoption in Central and Eastern Europe: A Comparative Analysis of Agricultural Water Management in Serbia. Environmental Politics, 19(4), 578-598, https://doi.org /10.1080/09644016.2010.489713

Greicevci, L. (2011). EU Actorness in International Affairs: The Case of EULEX Mission in Kosovo. Perspectives on European Politics and Society, 12(3), 283-303, https://doi.org/10.1080/15705854.2011.596307

Grillot, S. R. (2010). Guns in the Balkans: Controlling Small Arms and Light Weapons in Seven Western Balkan Countries. Southeast European and Black Sea Studies, 10(2), 147-171, https://doi.org/10.1080/14683857.2010.486945 
Grimm, S., \& Mathis, O. L. (2015). Stability First, Development Second, Democracy Third: The European Union's Policy Towards the Post-Conflict Western Balkans. Europe-Asia Studies, 67(6), 916-947, https://doi.org/10.1080/0 9668136.2015.1055237

Hills, A. (2004). Assumptions, Principles and Strategy. The Adelphi Papers, 44(371), 11-40, https://doi.org/10.1080/05679320412331340487

Jednak, S., Kragulj, D., Bulajic, M., \& Pittman, R. (2009). Electricity Reform in Serbia. Utilities Policy, 17(1), 125-133, https://doi.org/10.1016/j.jup.2008.02.002

Jusufi, I. (2018). Aid and Its Impact on Domestic Change: The Case of Police Reforms in Macedonia. Development Policy Review, 36(6), 743-758, https:// doi.org/10.1111/dpr.12343

Keane, R. (2005). The Partnership-Conditionality Binary in the Western Balkans: Promoting Local Ownership for Sustainable Democratic Transition. Cambridge Review of International Affairs, 18(2), 247-257, https://doi. org/10.1080/09557570500164678

Kelemen, R. D. (2002). The Politics of "Eurocratic" Structure and the New European Agencies. West European Politics, 25(4), 93-118, https://doi.org/10.1080/713601644

Kilibarda, K. (2011). Clearing Space: An Anatomy of Urban Renewal, Social Cleansing and Everyday Life in a Belgrade Mahala. Cambridge Review of International Affairs, 24(4), 593-612, https://doi.org/10.1080/09557571.2011.630380

Kirchner, E. (2013). Common Security and Defence Policy Peace Operations in the Western Balkans: Impact and Lessons Learned. European Security, 22(1), 36-54, https://doi.org/10.1080/09662839.2012.749865

Korkea-aho, E. (2016). Better Judicial Review? EU Courts and the Smart Regulation Agenda in Implementing Chemicals Regulation. Legisprudence, 6(3), 397-423, https://doi.org/10.5235/17521467.6.3.397

Kovács, G., Matopoulos, A., \& Hayes, O. (2010). A Community Based Approach to Supply Chain Design. International Journal of Logistics Research and Applications: A Leading Journal of Supply Chain Management, 13(5), 411-422, https:// doi.org/10.1080/13675567.2010.511609

Kreher, A. (1997). Agencies in the European Community - A Step Towards Administrative Integration in Europe. Journal of European Public Policy, 4(2), 225-245, https://doi.org/10.1080/13501769709696340

Kumkar, L. (2003). Regulatory Choices and Commitment: Challenges for Electricity Market Regulation in Kosovo. Post-Communist Economies, 15(1), 91-115, https://doi.org/10.1080/1463137032000058403

Lim, J. Y. (2021). The Evolution of Research on Organizational Termination. International Review of Administrative Sciences, 87(1), 191-207, https://doi. org/10.1177\%2F0020852319852663

Mace, C. (2004). Operation Concordia: Developing a "European" Approach to Crisis Management? International Peacekeeping, 11(3), 474-490, https://doi. org/10.1080/1353331042000249055

Minervini, C. (2002). Housing Reconstruction in Kosovo. Habitat International 26(4), 571-590, https://doi.org/10.1016/S0197-3975(02)00026-7 
Moldogaziev, T. T., Scott T. A., \& Greer, R. A. (2019). Organizational Dissolutions in the Public Sector: An Empirical Analysis of Municipal Utility Water Districts. Journal of Public Administration Research and Theory, 29(4), 535-555, https://doi.org/10.1093/jopart/muy081

Mortensen, P. B., \& Green-Pedersen, C. (2015). Institutional Effects of Changes in Political Attention: Explaining Organizational Changes in the Top Bureaucracy. Journal of Public Administration Research and Theory, 25(1), 165-189, https://doi.org/10.1093/jopart/muu030

Nieminen, K. (2006). Review Essay: The Difficult Equation of Long-Term Peace and Post-Conflict Governance. Security Dialogue, 37(2), 263-272, https://doi. org/10.1177\%2F0967010606066178

O'Leary, C. (2015). Agency Termination in the UK: What Explains the "Bonfire of the Quangos"? West European Politics, 38(6), 1327-1344, https://doi.org/10 $.1080 / 01402382.2015 .1010273$

Particip GmbH. (2009). Retrospective Evaluation of CARDS Programmes in Serbia and the Former Yugoslav Republic of Macedonia.

Pollak, J., \&Puntscher, S. R. (2008). European Administration: Centralisation and Fragmentation as Means of Polity-Building? West European Politics, 31(4), 771-788, https://doi.org/10.1080/01402380801906064

Presnall, A. (2009). Which Way the Wind Blows: Democracy Promotion and International Actors in Serbia. Democratization, 16(4), 661-681, https://doi. org/10.1080/13510340903083026

Radeljić, B. (2014). Official Discrepancies: Kosovo Independence and Western European Rhetoric. Perspectives on European Politics and Society, 15(4), 431444, https://doi.org/10.1080/15705854.2014.893706

Radovic, I., \& Luther, C. A. (2012). From State Controlled to Public Service Broadcasting: Signs of Change in Serbia's RTS Television Newscasts 19892009. Journal of Broadcasting \& Electronic Media, 56(2), 245-260, https://doi. org/10.1080/08838151.2012.678517

Ramboll (2009). Evaluation of the EU Decentralised Agencies in 2009: Agency level findings.

Reliefweb (1999). European Commission task force for Kosovo (TAFKO). Retrieved from https://reliefweb.int/report/serbia/european-commission-task-forcekosovo-tafko.

Rexha, I., \& Kopacek, P. (2010). Electronic Waste Management in Kosovo: An Important Contribution for Stability. Workshop on supplemental ways for improving international stability (SWIIS 2010). Prishtina, Kosovo. 27-29 October 2010.

Rittberger, B., \& Wonka, A. (2011). Introduction: Agency Governance in the European Union. Journal of European Public Policy, 18(6), 780-789, https://doi. org/10.1080/13501763.2011.593356

Roederer-Rynning, C., \& Daugbjerg, C. (2010). Power, Learning, or Path Dependency? Investigating the Roots of the European Food Safety Authority. Public Administration, 88(2), 315-30, https://doi.org/10.1111/j.1467-9299.2010.01832.x 
Ryan, B. J. (2009). The EU's Mergent Security-First Agenda: Securing Albania and Montenegro. Security Dialogue, 40(3), 311-331, https://doi. org/10.1177\%2F0967010609336195

Simić, S., Šantrić Milićević, M., Matejić, B., Marinković, J., \& Adams, O. (2010). Do We Have Primary Health Care Reform? The Story of the Republic of Serbia. Health Policy, 96(2), 160-169, https://doi.org/10.1016/j.healthpol.2010.01.015

Stewart, E. J. (2008). Restoring EU-OSCE Cooperation for Pan-European Conflict Prevention. Contemporary Security Policy, 29(2), 266-284, https://doi. org/10.1080/13523260802284126

Supic, Z., Bjegovic, V., Marinkovic, J., Santric Milicevic, M., \& Vasic, V. (2010). Hospital Management Training and Improvement in Managerial Skills: Serbian Experience. Health Policy, 96(1), 80-89, https://doi.org/10.1016/j.healthpol.2010.01.002

Taleski, R. (2009). Electricity Reform in the Republic of Macedonia. Utilities Policy, 17(), 88-101, https://doi.org/10.1016/j.jup.2008.02.003

Tenner, S. (2010). Gast:Arbajterski R:Adio - Migration and Media in Serbia. Telematics and Informatics, 27(2), 177-181, https://doi.org/10.1016/j.tele.2009.06.003

Tsoukalis, L. (1999). Economic Aspects of European and Balkan Regional Integration. The International Spectator: Italian Journal of International Affairs, 34(4), 41-48, https://doi.org/10.1080/03932729908456887

Tzifakis, N. (2013). The European Union in Kosovo: Reflecting on the Credibility and Efficiency Deficit. Problems of Post-Communism, 60(1), 43-54, https://doi. org/10.2753/PPC1075-8216600104

Vrbensky, R. (2009). Can Development Prevent Conflict? Integrated Area-Based Development in the Western Balkans. Conflict, Security \& Development, 9(1), 75-110, https://doi.org/10.1080/14678800802704929

Wonka, A., \& Rittberger, B. (2010). Credibility, Complexity and Uncertainty: Explaining the Institutional Independence of 29 EU Agencies. West European Politics, 33(4), 730-752, https://doi.org/10.1080/01402381003794597 


\title{
THE DEATH OF THE EUROPEAN AGENCY FOR RECONSTRUCTION: A PECULIAR CASE OF TERMINATION OF THE AGENCIES OF THE EUROPEAN UNION
}

\begin{abstract}
Summary
Almost each EU member states hosts an EU agency that deals with some issues related to acquis communautaire. From many issues as regards the work and functioning of the EU agencies, the issue of their institutional design is an important aspect to consider. In this context, various changes have been observed in the operations of the EU agencies. The European Agency for Reconstruction (EAR), an EU agency that managed the EU aid to the Western Balkans from 2000 to 2008, proved to be an efficient and effective agency in delivering aid, considering the EU's cumbersome procedures for contracting and disbursement of the aid. However, the EAR was closed in 2008 despite its successful record. Thus, it is important to consider the case of the EAR and institutional design it offered. By examining the EAR, the paper assesses its structure and operations as a particular institutional design. The paper provides a picture of a comparative model of the EAR in the framework of current EU agencies and their operations. It addresses a set of questions that occupy scholarly work as regards the EU agencies. The paper provides explanations to account for the reasons of the establishment, closure and institutional design of the EAR. The EAR as an EU agency operating in the field of aid management showed some level of independence. Thus, the paper finds evidence that politicization of aid had an impact on the de facto independence of the EAR. While the EAR had autonomy and independence, the way this agency was designed guaranteed the Council and the Commission an important role in the direct control of bow the EAR performed its tasks.
\end{abstract}

Keywords: EU, agencies, European Agency for Reconstruction, institutional termination, Western Balkans 


\title{
SMRT EUROPSKE AGENCIJE ZA OBNOVU: POSEBAN SLUČAJ PRESTANKA AGENCIJA EUROPSKE UNIJE
}

\begin{abstract}
Sažetak
Gotovo svaka država članica Europske unije udomljuje agenciju koja se bavi nekim pitanjima vezanim uz pravnu stečevinu EU-a. Od mnogih pitanja vezanib uz rad i funkcioniranje agencija EU-a važno je razmotriti pitanje njibova institucijskog dizajna. U tom kontekstu uočene su različite promjene u djelovanju agencija EU-a. Europska agencija za obnovu (EAO) koja je upravljala pomoći EU-a zapadnom Balkanu od 2000. do 2008. pokazala se djelotvornom $i$ učinkovitom agencijom u pružanju pomoći s obzirom na glomazne procedure EU-a za ugovaranje i isplatu pomoći. Medutim, EAO je zatvoren 2008. unatoč uspješnim pokazateljima. Stoga je važno razmotriti slučaj EAOa $i$ institucijski dizajn koji je ponudio. Analizom EAO-a u radu se procjenjuje njegova struktura $i$ djelovanje kao poseban slučaj institucijskog dizajna. Rad daje sliku komparativnog modela EAO-a u kontekstu rada aktualnib agencija EU-a. Obrađuje niz pitanja koja zaokupljaju znanstveni interes u vezi s agencijama EU-a. U radu se donose objašnjenja za razloge osnivanja, ukidanja $i$ institucijskog oblikovanja EAO-a. EAO kao agencija EU-a koja je djelovala u području upravljanja pomoći pokazala je određenu razinu neovisnosti. Stoga rad nalazi dokaze da je, budući da je pomoć bila politizirana, to utjecalo na de facto neovisnost EAO-a. Iako je EAO imao autonomiju i neovisnost, način na koji je EAO osmišljen jamčio je Vijeću i Komisiji važnu ulogu u izravnoj kontroli načina na koji EAO obavlja svoje zadaće.

Ključne riječi: EU, agencije, Europska agencija za obnovu, institucijsko ukidanje, zapadni Balkan
\end{abstract}

